\title{
Paleocene and Eocene floristic and climatic change in Russia and Northern Kazakhstan
}

\author{
MIKHAIL A. AKHMETIEV
}

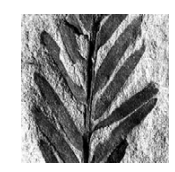

\begin{abstract}
Paleocene and Eocene floras of Russia and adjacent regions are reviewed with an interpretation of climatic conditions under which they developed. Floristic and climatic changes in western and central regions of Russia in the Paleocene and in the first part of the Eocene were caused by the dynamics and rearrangement of the systems of marine seaways: a longitudinal seaway, which connected the Arctic basin with the marginal seas of Northern Peri-Tethys (Turanian, South Russian and others), and a latitudinal seaway, which connected the marginal seas of Northern Peri-Tethys with the Atlantic Ocean. As these systems were progressively reduced, the climate in the middle latitudes changed from paratropical (like in West and Central Europe) to a subtropical monsoon climate with wet summers (Late Ypresian to Lutetian), and later to a climate with wet winters (Late Lutetian to the first part of the Priabonian). Floristic changes reflect these climatic trends. In the Paleogene, cold currents constantly influenced the climate of regions of the northwestern Pacific and facilitated development of a warm-temperate mesophilic flora. A warmer episode took place in the Early Eocene. At this time thermophilic plants (Sabal, Myrtaceae and Lauraceae) reached Koryakia, North Western Kamchatka, probably as a result of northward migration. Some subtropical plants existed near the Recent Polar circle. The subtropical Raichikha-type Flora lost temperate elements and, by ecological and climatic types, it is more similar to the Recent flora of South-West and South China. • Key words: flora, palaeoclimate, Paleocene, Eocene, Russia.
\end{abstract}

AKhmetiev, M.A. 2010. Paleocene and Eocene floristic and climatic change in Russia and Northern Kazakhstan. Bulletin of Geosciences 85(1), 77-94 (7 figures). Czech Geological Survey, Prague. ISSN 1214-1119. Manuscript received May 6, 2009; accepted in revised form October 5, 2009; published online January 8, 2010; issued March $22,2010$.

Mikhail A. Akhmetiev, Geological Institute of the Russian Academy of Sciences, Pyzhevsky by-street 7, 119017 Moscow, Russia; akhmetiev@ginras.ru

The quality of information about the Paleocene and Eocene floras in Russia is very variable. Little is known about the floras from the northern and central parts of the East European and Siberian platforms. Most localities are distributed along the coast of the Northern Peri-Tethys seas (South Russian, Turanian, West Siberian) and along the West Pacific periphery. Plant macrofossils are usually preserved in lacustrine and alluvial sediments of coastal plains or, more rarely, in intermontane coal-bearing sedimentary basins as well as around volcanic structures. Figs 1-4 show the main localities yielding plant macrofossils. Seas, straits and key palaeogeographic areas are named in Fig. 2.

\section{Danian floras (Fig. 1)}

At the K/T boundary, a transition to the warm temperate Tsagayan flora was first studied from the Tsagayan Series of the Zeya-Bureya sedimentary basin (Fig. 1, locs 5, 6) that developed on the continental boundary of the Western
Pacific. Onoclea, Osmunda, Ginkgo, Taxodiaceae, Cupressaceae, Trochodendroides, Cornaceae, Hamamelidaceae, Nyssaceae (Akhmetiev et al. 2002) and some other taxa are the most typical members of this flora. Trochodendroides is a key indicator taxon for these floras (Fig. 1 Tr). To date, at least 70 species of the Tsagayan flora have been recognized. Contemporary floras of the Tsagayan ecotype are known from areas adjacent to the Amur River Area: southern Primorye, Sakhalin, Sikhote-Alin volcanic belts (Malo-Mikhailovka and Takhobe localities), Kamchatka and Koryakia (Fig. 1, locs 7-10). These floras are discussed in the final section of this paper.

At high latitudes, the warm temperate humid flora migrated westward along the northern boundary of the West Siberian plate and in the Danian reached the northern and Middle Urals (Lozva flora, Fig. 1, loc. 1). The same type of the Danian flora occupied the Arctic region: Spitzbergen, Greenland, North Canada, Alaska and northern Siberia many localities at the Lena River Mouth area and Kharaulakh ridge (Bykov arm of the Lena River, Kengdey and Kungi grabens) (Budantsev 1983). Tsagayan plants 


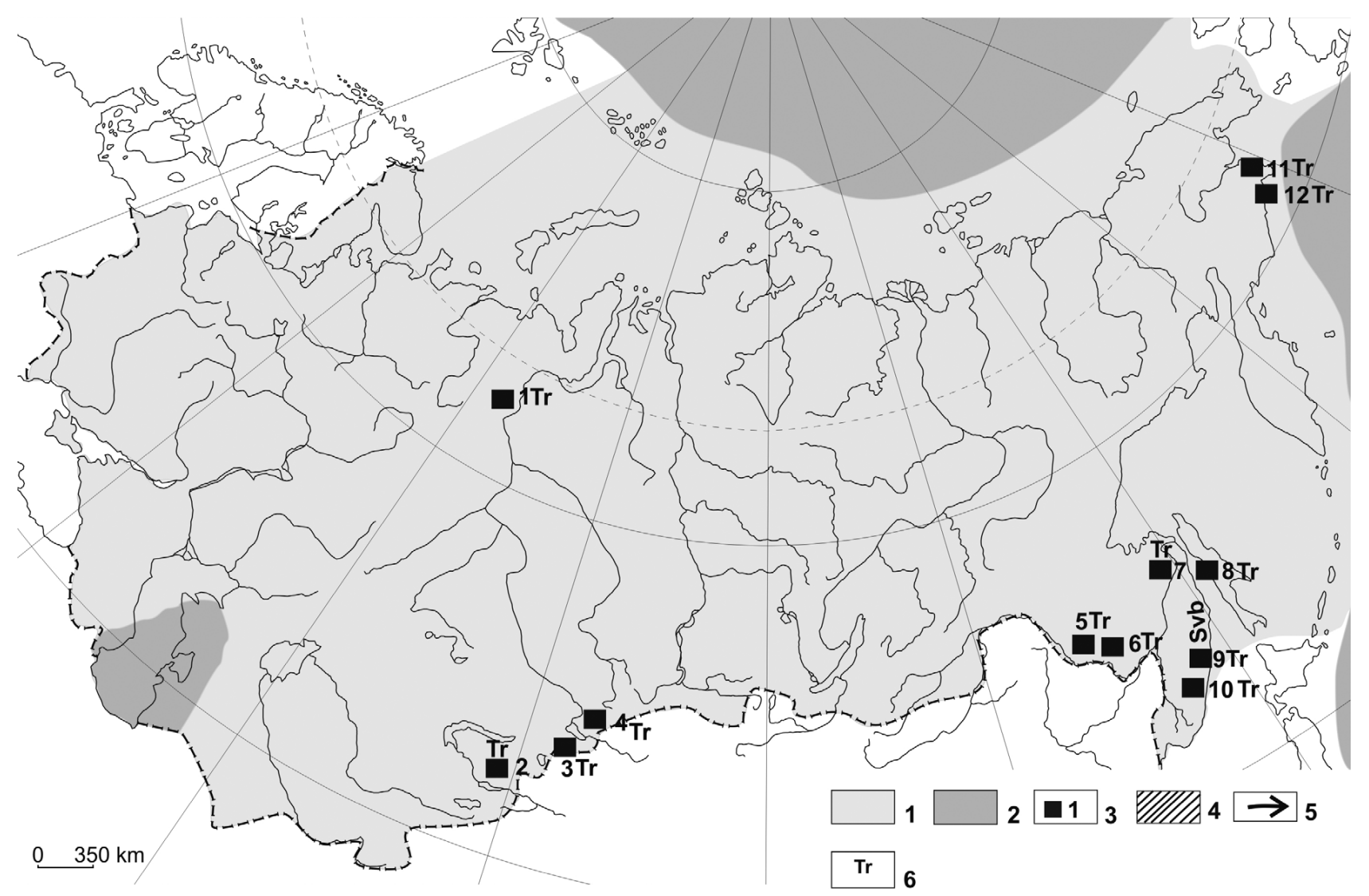

Figure 1-4. Palaeogeographic maps and main localities for Paleocene and Eocene floras (within the boundaries of the former USSR). Legend (see Fig. 1): 1 - land, 2 - sea, 3 - locality and its number on maps, 4 - areas of bauxitization, 5 - direction of sea currents, 6 - plant indicators: Tr - Trochodendroides, U - Ushia, S - Sabal, N-Nypa, P - Palibinia. All geographical and paleogeographical elements are shown in Fig. 2.

Figure 1. Early Danian. Localities: 1 - Lozva (western border of Western Siberian Plate) (Tr), 2 - Ulken-Kalkan (Ili River Basin, Kazakhstan) (Tr), 3 - Taizhusgen (Zaissan Lake basin) (Tr), 4 - Kara Biryuk (Zaissan Lake basin) (Tr), 5 - Raichikha coal field and Belaya Mount (Tsagayan flora - type locality) (Tr), 6 - Arkhara-Bouguchan coal field (Tr) (locality 5 and 6 - Zeya-Bureya sedimentary basin, Amur River Area), 7 - Malo-Mikhailovka (Lower Amur Area) (Tr), 8 - Kama River Area (Western Sakhalin) (Tr), 9 - Sobolevka (= Takhobe) (Eastern Sikhote-Alin) (Tr), 10 - Zerkalnaya (= Tadushi) (Eastern Sikhote-Alin) (Tr), 11 - Rarytkin Ridge (Northern Koryakia) (Tr), 12 - Beringovsky (Beringian sea, Anadyr Bay) (Tchukotskaya Formation) (Tr), Svb - Sikhote-Alin volcanic belt.

migrated westward along the mid-latitude tracts from the Amur River system and reached Mongolia, Dzhungarian Alatau, Ili River area (Ulken Kalkan), Semipalatinsk district on the Irtysh River area and the Zaissan Lake basin (South Eastern Kazakhstan) (Fig. 1, locs 2-4). In the Danian the Kara-Biryuk flora (Fig. 1, loc. 4) in the Zaissan Lake basin includes typical Tsagayan plants: Taxites olrikii, Trochodendroides arctica, Nyssa bureica, Platanus raynoldsii, Porosia and others.

In the Zeya-Bureya sedimentary basin (area of localities 5 and 6 in Fig. 1), the Tsagayan flora went through three stages of evolution from Middle Tsagayan to Kivda time (early Danian-?Selandian) (Kivda Flora see Fig. 1, loc. 5). The youngest flora of the Tsagayan ecotypes is characterized by various new members initially Myricaceae and Betulaceae as well as Ulmaceae. It should be noted that no principal changes in composition of the Tsagayan flora took place in the Danian and possibly, in the Late Paleocene. For each stage, only five to seven new taxa (up to $10 \%$ of total) appeared, and approximately the same number of taxa disappeared.

There is the typical Danian Flora in the central part of the Rarytkin Ridge (North Koryakia, Fig. 1, loc. 11) and a similar flora from Sakhalin (Kama River beds, Fig. 1, loc. 8) (Kodrul 1999).

\section{Later Paleocene and Eocene floras of Northern Central Eurasia}

Two main marine systems influenced the development of the Paleogene flora and vegetation in European Russia and Siberia. 1) A meridional system that connected the Tethys with the Arctic Basin via the West Siberian epicontinental sea and the Turgai strait. 2) A latitudinal system that connected the East Peritethys with the Atlantic Ocean through 


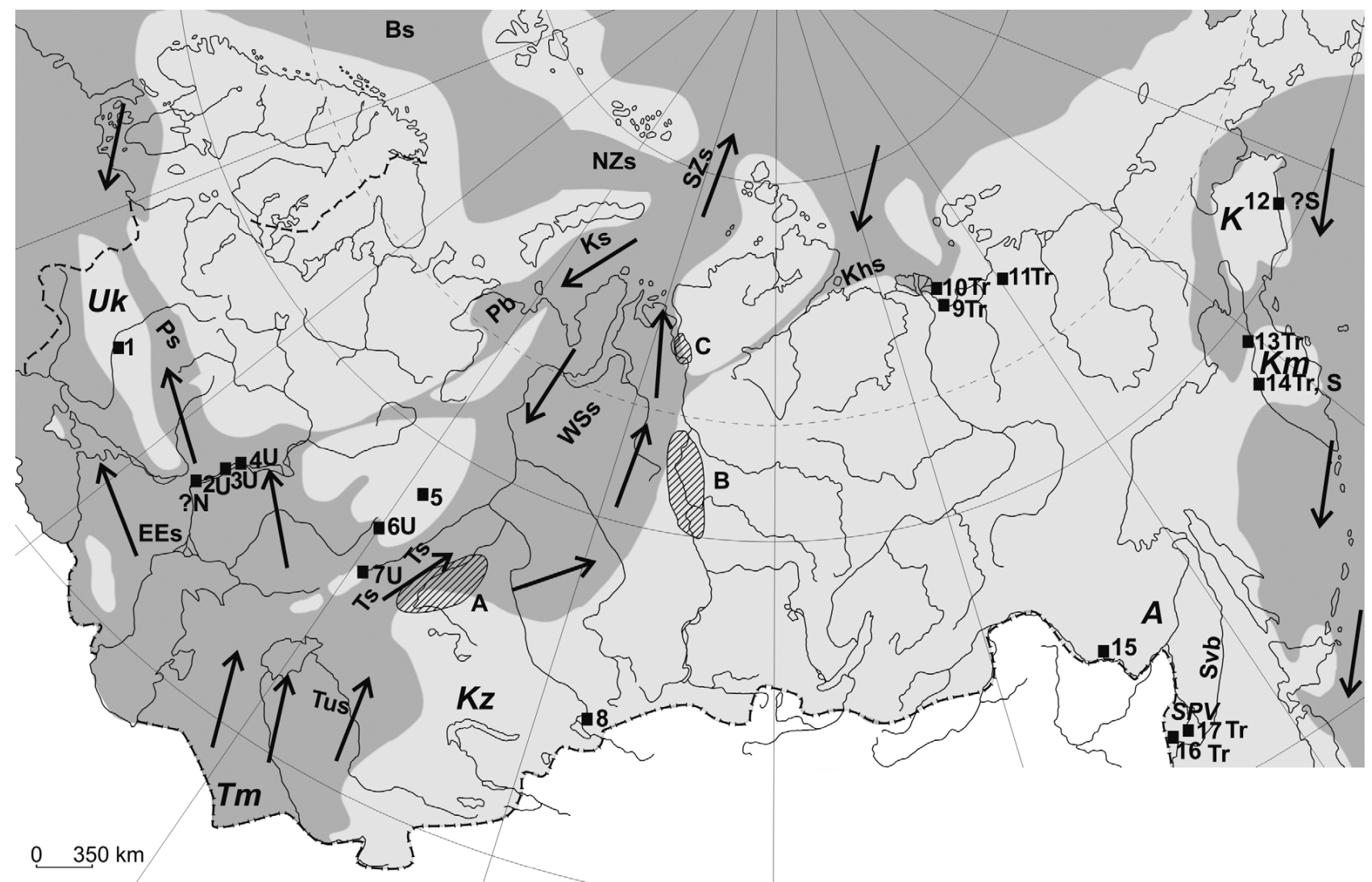

Figure 2. Late Thanetian-Early Ypresian (including the PETM Episode). Localities: 1 - Kanev (Dnieper River Area, Southern Kiev), 2 - Kamyshin (Volga River Area (U, ?N), 3 - Nikulino-Privolsk (Volga River Area, northern of Saratov) (U), 4 - Akshuat - Tashly (northern of Saratov) (U), 5 - Smolino (South Ural, near Tchelyabinsk), 6 - Romankol (Or River Area, Northern Kazakhstan) (U), 7 - Tykbutak (Mugodzary Mounntain, Northern Kazakhstan) (U), 8 - Kiin-Kerish (Zaissan Lake Basin, brown clays "flora"), 9 - Kengday and Kunga troughs (Lower Lena River Area) (Tr), 10 - Bykovo channel (Lower Lena River Area) (Tr), 11 - Tas-Takh Lake (northern part of Siberian platform) (Tr), 12 - Beringovsky (Beringian Sea, Anadyr Bay) (Sandstones Member with ?Sabal), 13 - Tchemurnaut (Western Kamchatka) (Tr), 14 - Rebro Cape (Western Kamchatka) (Tr, S), 15 - Raichikha (Raichikhinsk coal field, Zeya - Bureya sedimentary basin), 16 - Rechnoi peninsula (northern of Vladivostok), Lower coal-bearing Member (Tr), 17 - Maikhe coal-bearing field (eastern of Vladivostok) (Tr).

Areas of bauxitization: A - Arkalyk, B - Yenisei-Angara Area, C - Lower Yenisei River Area.

$U k$ - Ukraine, $K z$ - Kazakhstan, $K$ - Koryakia, $K m$ - Kamchatka, SPV - South Primorie, Vladivostok, $A$ - Amur River basin, Tm - Turkmenia. Bs - Barents sea, NZs - "Novaya Zemlya" strait, SZs -"Severnaya Zemlya" strait, Khs - Khatanga strait, WSs - West Siberian sea, Ks - Kara sea, $\mathrm{Pb}$ - Pechora bay, Ts - Turgayan strait, EEs - Eastern European sea, Tus - Turanian sea. Ps - Pripyat strait, Svb - Sikhote-Alin volcanic belt.

the Dnieper-Donetsk Sea and western (Pripyat and Polish) straits (Akhmetiev \& Beniamovski 2006).

\section{Paleocene and Early Eocene evergreen thermophilic flora west of the Urals} (Fig. 2, localities 1-4) and Kazakhstan (Fig. 2, localities 6-8)

Since the Danian, a Tethys Gelinden ecotype thermophilic flora, with mostly evergreen aspects, developed to the west of the Ural mountain range under a humid "paratropical" climate.

During the Selandian and the Thanetian the core of the paratropical flora was formed by the Ushia assemblage (Fig. 2 - localities with U) with Chamaecyparis, Ushia,
Dewalquea, Macclintockia, Dryophyllum and Lauraceae. This assemblage was found in several localities from the Volga basin in the Ulyanovsk and Saratov districts (Fig. 2, locs 2-4). The Kamyshin Flora contains Ushia in different morphotypes, which are described as species: Ushia kamyschinensis (Goepp.) Kolakovsky, U. alnifolia Makulbekov, U. janishevskii Makulbekov, etc.) as well as Lauraceae (Daphnogene lanceolata Ung., Litsea sp., Ocotea sp., Persea paleomorpha Sap., P. enormis (Krasnov) Makulbekov, Dewalquea gelindensis Sap. \& Mar., Oxycarpia bifaria Tautsch., Ficus murczisonii Makulbekov, Viburnum volgensie Krasnov, and others (Krasnov 1910, Makulbekov 1977, Mai 1995). In the Late Paleocene the Ushia-type flora spread to North Kazakhstan. The Romankol flora (Fig. 2, loc. 6) from the Paleocene-Eocene transition (corresponding with climatic optimum - PETM) 


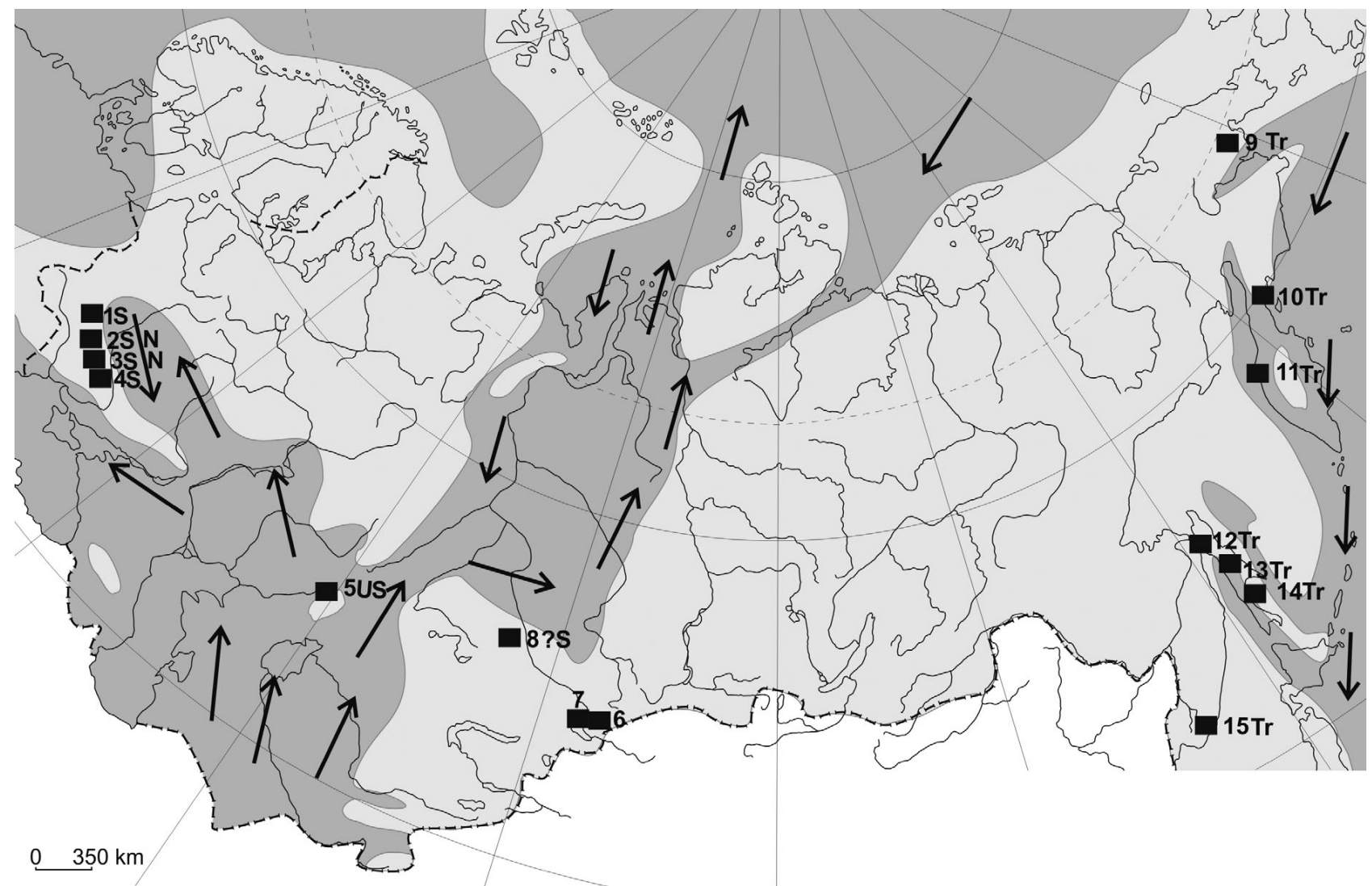

Figure 3. Late Ypresian-Early Lutetian. Localities: 1 - Mogilno (western of Kiev) (S), 2 - Kremyanka (western of Kiev) (S), 3 - Zvenigorodka (Yekaterinopolye, Dniper River Area, south-eastern of Kiev), (Bouchak Formation) (S), 4 - Adzhamka (Dnieper River Area, south-eastern of Kiev) (Bouchak Formation) (S), 5 - Karakol (Mugodzhary Mountain, Northern Kazakhstan) (U), 6 - Chakelmes (Zaissan Lake Basin), 7 - Kershi (Zaissan Lake Basin), 8 - Karasor (North-Western Kazakhstan, Irtysh River Area) (?S), 9 - Northern Koryakia (Circus Mount) (Tr), 10 - Kangpil Cape (Penzhinsky Bay) (Tr), 11 - Snatol (Palana) (Western Kamchatka) (Tr), 12 - Due (Western Sakhalin) (Conglomerate and Lower Due formations) (Tr), 13 - Snezhinka (Lower Snezhinka Subformation) (Western Sakhalin) (Tr), 14 - Krasnoyarka River (Naibuti Formation) (South-Eastern Sakhalin) (Tr), 15 - Artyem Coal field (north-western of Vladivostok) (Uglovoye Formation) (Tr).

included Ushia and various evergreen plants belonging to Moraceae (Artocarpus, Ficus), Proteaceae (Dryandra), Magnoliaceae, Lauraceae (6 genera), Euphorbiaceae, Elaeocarpaceae, Sterculiaceae, Combretaceae, Myrtaceae, Theaceae, Melastomataceae, Araliaceae, Sapotaceae (Sideroxylon), Symplocaceae, Apocynaceae etc. (Makulbekov 1977, Baikovskaya 1984, Akhmetiev 2007).

The Tykbutak locality (Fig. 2, loc. 7, Mugodzary Mountain, Northern Kazakhstan) was studied by N.M. Makulbekov (1977). The fossils were collected from the Tykbutak Formation. This formation consists of alternate sands, sandstones (predominate), sandy clays, and a form of chert (a fine grained porous siliceous sedimentary rock with small proportions of sand) [the Russian term for the latter is opoka or gaises which seems to have no exact English equivalent]. Most of the leaves have entire margins and belong to subtropical or tropical genera and families: Quasisequoia couttsiae (Heer) Kunzmann, Glyptostrobus sp., Magnolia embica Makulbekov, different Lauraceae (dominants, belong to Persea, Litsea, Laurus, Lauro- phyllum, Apollonias, Daphnogene, Phoebe), Ficus sp., Ushia sp. (several morphotypes), Myrica banksiaefolia Ung., Leucothoë protogaea (Ung.) Schimp., Bumelia oblongifolia Ett., Mimosites sp., Callistemophyllum melaleucaeforme Ett., Sapindus sp., Aralia venulosa Sap. \& Mar., Celastrophyllum sp., (?)Dryandra karakulensis Baranova, Poaceae gen., Dewalquea gelindensis Sap. \& Mar. and others.

Locality 8 (Fig. 2) is situated on the northern Zaissan Lake, on the western part of the Kiin-Kerish hill. Iljinskaya (1963), Romanova (1970) and Akhmetiev (1985) studied "Brown clays flora" at the base of the North-Zaissan Group. The composition of this flora changed from base to top of the sequence. Near the base aquatic or semi-aquatic plants predominated, such as Peltandra, Zingiberopsis, Nelumbo, Salvinia, Anoectomeria brongniartii Sap., Nymphaea polyrhiza Sap., Carex sp., Cyperacites sp., Poacites sp., Phragmites sp. The rarer Protoacerophyllum perfoliatum Romanova is also found near the base. Some aquatic plants are like those from the Early Eocene Raichikha flora 
Amur River basin (Salvinia, Peltandra, Zingiberopsis, Nelumbo, Nymphaea). Both floras are characterized by reduction in conifers. This is a typical oxbow-lake assemblage. To the top of the section aquatic or semi-aquatic plants are reduced and different narrow leaved angiosperms appear, some of them endemics: "Begonia" vachrameevii Romanova, "Oxicarpia" microcarpa Romanova, Protophyllum zaissanicum Romanova, Arthollia (Zaissania) spp. Among narrow-leaved endemic species there are Dryophyllum curticellense (Wat.) Sap. \& Mar., Lindera vassilenkoi Iljinskaya, Lauraceae gen., Apocynophyllum iljinskajae Romanova and others.

In Western Ukraine the Kanev Formation (Fig. 2, loc. 1) included clays and marls with rich Early Ypresian microfossil assemblages (planktonic foraminifera, nannoplankton, dinocysts) distributed along the Dnieper valley from South to North Kiev. A.N. Kryshtofovich described several species: Posidonia parisiensis (Desm.) Frittel, Arunidites roginei (Wat.) Frittel, Macclintockia kanei (Heer) Sap., Hakea spathulata Schmal., two small leaves similar to Lauraceae genera and Andromeda sp. (Leucothoë sp.) (see Baranov 1959, p. 71).

Bauxite (another indicator of warm wet subtropical climate) occurs in the Early Eocene in different areas of Kazakhstan and Siberia (Fig. 2). These include the areas near the Turgai-Arkalyk district of North Kazakhstan, along the Siberian platform (right side of the Yenisey River valley) from south to east along the south part of the Yenisey ridge $\left(60^{\circ}\right.$ north latitude) up to $67^{\circ} \mathrm{N}$. Some studies show that the ore was found near the Yenisey River mouth $\left(70^{\circ} \mathrm{N}\right)$ (Bushinsky 1958).

\section{Late Ypresian subtropical humid forests, central Eurasia (Fig. 3, locality 5)}

By the Late Ypresian the central Eurasian paratropical climate changed to a summer-wet monsoon-type of subtropical climate. This change was probably connected with interrupted latitudinal communications between the western and eastern North Peri-Tethys seas. A land barrier was formed on the Pripyat strait (Akhmetiev \& Beniamovski 2006). By the Early Lutetian the inner marine seas began to shallow and showed signs of reduction of the longitudinal straits connecting the Arctic basin with the Tethys through theTurgai strait and West Siberian Sea. The Orsk-Ayat strait in the southern Ural disappeared. The West Siberian Sea also reduced, but southern transfer of heat and moisture continued elsewhere. Seasonal redistribution of precipitation took place. Early Paleogene paratropical forests changed to subtropical humid forests as a result of the onset of a monsoon summer-wet climate. These forests included Lauraceae (Persea, Litsea, Daphnogene) and Fagaceae, especially Castanopsis, and also
Lithocarpus, Dryophyllum and large-leaved Quercus predominated and also Magnolia, Sterculia, Leguminophyllum and other woody elements. Such assemblages were documented by Makulbekov (1972, 1977) at Karakol (Cis-Irtysian) (about 50\% Castanopsis) and Sarkol (Mugodzhary) (both Fig. 3, loc. 5). Floristic layers with Castanopsis overlap with the Lower Member of the Tykbutak Formation with Ushia.

Late Ypresian-Lutetian, Ukraine (Fig. 3, localities 1-4), North-Eastern Kazakhstan (Fig. 3, locality 8), Zaissan Lake Basin (Fig. 3, localities 6, 7)

To the west in Ukraine a large-leaved flora similar to that in Central Eurasia was described from the coal-bearing Buchak Formation (Lutetian). Most localities are concentrated south of Kiev, Volynian (Mogilno locality, Fig. 3, loc. 1), and Dnieper River areas [Kremyanka (Fig. 3, locs 2-4) (N), Jablontsy localities and others] (Schmalhausen 1883-1884, Kryshtofovich 1927, Pimenova 1937, Stanislavsky 1950, Zhilin 1986). Sabal (Fig. 3 - S) is an important consituent of these floras. The main components of these floras were Lauraceae (Daphnogene, Cinnamomophyllum, Laurus, Persea), Fagaceae (Dryophyllum, Eotrigonobalanus, Lithocarpus, Castanopsis), evergreen plants represented by Ficus, Palmae (Sabal and Nypa), Magnolia, Myrtophyllum, Myrsine, Pittosporum etc. Ferns (Lygodium) and conifers (Doliostrobus, Quasisequoia) were very rare. Early Lutetian clays with Spondylos can be followed along the right side of the Dniper Valley from Kiev to Yekaterinopolye (Fig. 3, loc. 3). Several localities with Nypa burtinii occur in this zone together with the typical mangrove fern Acrostichum.

Two localities with Late Ypresian-Early Bartonian floras were found near the Zaissan Lake (South-Eastern Kazakhstan). The first of them is Chakelmes hill (Fig. 3, loc. 6). Dominants of the Chakelmes flora are Taxodiaceae, Dryophyllum curticellense (Wat.) Sap. \& Mar., D. dewalquei Sap. \& Mar., D. kryshtofovichii Iljinskaya, different Lauraceae (dominant, more then $80 \%$ specimens, determined by epidermal investigation) and Zingiberopsis sp. More rarely encountered are Sequoia sp., Taxodium dubium (Sternb.) Heer, Glyptostrobus sp., Cryptomeria sp., Magnolia sp., Populus kryshtofovichii Iljinskaya, Lindera sp., Apocynophyllum sp. and others (Iljinskaya 1986, Akhmetiev 1993).

The second flora is from Kershi (a small hill in the northern Zaissan Lake area) (Fig. 3, loc. 7). This is a typical sclerophyllous subtropical-type flora. E.V. Romanova and I.A. Iljinskaya recognized more than ten species: Liquidambar kazakhstanica Romanova, Ficus sp., Coccoloba sp., Sterculia sp., Cassia sp., Eugenia kirshiensis Romanova, 
Idesia romanovii Iljinskaya, Ungnadia kryshtofovichii Iljinskaya and others (Iljinskaya 1986).

The typical monsoon-type subtropical flora is found in Karasor (North Eastern Kazakhstan, Irtysh River area) (Makulbekov 1972) (Fig. 3, loc. 8). The main components of this flora are Fagaceae, especially Castanopsis (more than $50 \%$ C. kazachstanensis Makulbekov and C. pavlodarensis Makulbekov), Quercus kornilovae Makulbekov, Q. irtyshensis Makulbekov, Quercus spp., Dryophyllum curticellense (Wat.) Sap. \& Mar., Dryophyllum dewalquei Sap. \& Mar. More rarely found are "Podocarpus" eocenica, Lauraceae (Persea, Cinnamomum, Litsea), Myrica spp., Leucothoe protogaea (Ung.) Schimp., Diospyros sp., Sterculia kalkamanica Makulbekov, Leguminosae gen., Eugenia haeringiana Ung., Lomatia macrophylla Makulbekov, Echitonium sp., Palmophyllum sp. and others.

Late Eocene, mixed evergreen deciduous, amber flora, Sambian peninsula, Baltic Region (Fig. 4, locality 22)

The Late Eocene flora of the Sambian peninsula (Baltic Region, Kaliningrad district) is unusual. It is represented by equal amounts of evergreen and deciduous plants. It is preserved in pieces of amber as inclusions of flowers, fruits and fragments of leaves. Fossil plant remains belong, besides angiosperms, to mosses, ferns, Pinus needles and reproductive organs, Cupressaceae and rare Taxodiaceae. About two hundred species of angiosperms (especially fruits and seeds) were described including evergreen Fagaceae, Lauraceae, Anacardiaceae, Hamamelidaceae, Araliaceae and others (Conwents 1886, 1890). This flora characterizes an ecotonal zone between the Boreal and Tethys realms.

\section{Bartonian, sclerophyllous flora, Ukraine to Kazakhstan (Fig. 4, localities 5-9, 12, 13), and Turkmenia (Fig. 4, localities 10, 11)}

A xerophytic Bartonian flora is distributed in the latitudinal zone from northern Ukraine through the Voronezh anticline, southern Ural and Mugodzhary to eastern Kazakhstan (Pavlodarian Irtysh River area). The localities often contain Palibinia (Fig. 4-P) as an important indicator taxon. Plant remains are preserved in red cavernous quartzite sandstones and represent mostly chaotically twisted small and narrow sclerophyllous leaves of angiosperms and conifers. Empty holes in the rock resulted after plant tissues of trunks and branches decayed after being covered by eolian sands and dust-like particles. The quartzite sandstones are younger than the Late Lutetian just after the meridional marine communication between the Tethys and Arctic basins ceased. The warm current continued from Tethys to the surviving large West Siberian marine gulf separated by a land barrier from the Arctic Basin. The climate changed and monsoon summer-wet climate was replaced by seasonal winter-wet climate, similar to that of the present region of the Mediterranean.

The floral lists herein are based on (i) the author's own collection of the xerophytic flora from the Baky locality (Fig. 4, loc. 5), southern Ural, (ii) the author's revisions of other collections from Baky made by M.D. Usnadze-Dgebuadze and N.M. Makulbekov and (iii) the author's revisions of collections from neighboring areas: Mugadzhary, Emba River area and Pavlodar district (Cisirtysh area), which were studied by A.N. Kryshtofovich, V.I. Baranov, L.Y. Budantsev, I.V. Vassiliev and V.S. Kornilova during the 1950-1970s.

After the revision, the flora contains some conifers ("Sequoia", "Podocarpus") and angiosperms, such as Macclintockia (=Majanthemophyllum), some Myricaceae, Fagaceae and Fabaceae. The typical Baky flora and other floras of the same composition from the Or' - Ilek watershed (Romankol, upper floristic layers, Zharlykap, Fig. 4, loc. 6 with Sabal, Fagaceae gen. (evergreen), Leucothoë, Palibina and others) and Or' River, South Urals (Fig. 4, loc. 7) with Cupressaceae and small sclerophyllous leaves Angiospermae), Mugodzhary, Pavlodar district [Takyrsor (Fig. 4, loc. 13), Zhaman Tuz (Fig. 4, loc. 12 - Makulbekov 1972] include Athrotaxis, ?Doliostrobus, Cupressaceae gen. indet, Laurophyllum, Myrica, Rhodomyrtophyllum, Quercus, Eotrigonobalanus, Leucothö, Majanthemophyllum, Leguminophyllum (different species), Echitonium etc. This list can be complemented by plants which are not represented in our collection: Palibinia (small sclerophyll narrow lobed leaves similar to those of Comptonia or Dryandra), Sabal and some others (data from N.D. Vassilevskaya). Southern Uralian and Mugodzharian species of Palibinia match the Badkhys Palibinia that Korovin $(1932,1934)$ described from the Bartonian Turkestan regional stage.

The Akar-Cheshme flora (Western Badkhyz, Turkmenia) (Fig. 4, loc. 10) with Palibinia, was discovered by N.D. Vassilevskaya (1957). Fossil plants are concentrated in thin ash layers (Andesite-dacite tuffaceus Member) underlying and overlapping marine clays with Bartonian planktonic foraminifera and nannoplankton assemblages. The Akar-Cheshme assemblage consists of different endemic ferns and angiosperms conifers are absent. There were determined by N.D.Vassilevskaya: Blechnum akartscheschmens Vassilevskaya, Lastraea badchyzica Vassilevskaya, Polypodites nepphrotiopsis Vassilevskaya, Myrica dilodendrofolia Vassilevskaya (dominant), Carya typica Vassilevskaya, Banksia myricifolia Vassilevskaya, Lauraceae (Ocotea, Laurus), Amygdalus turcmenensis Vassilevskaya, Leguminosae gen., Anacardites badchyzicus 


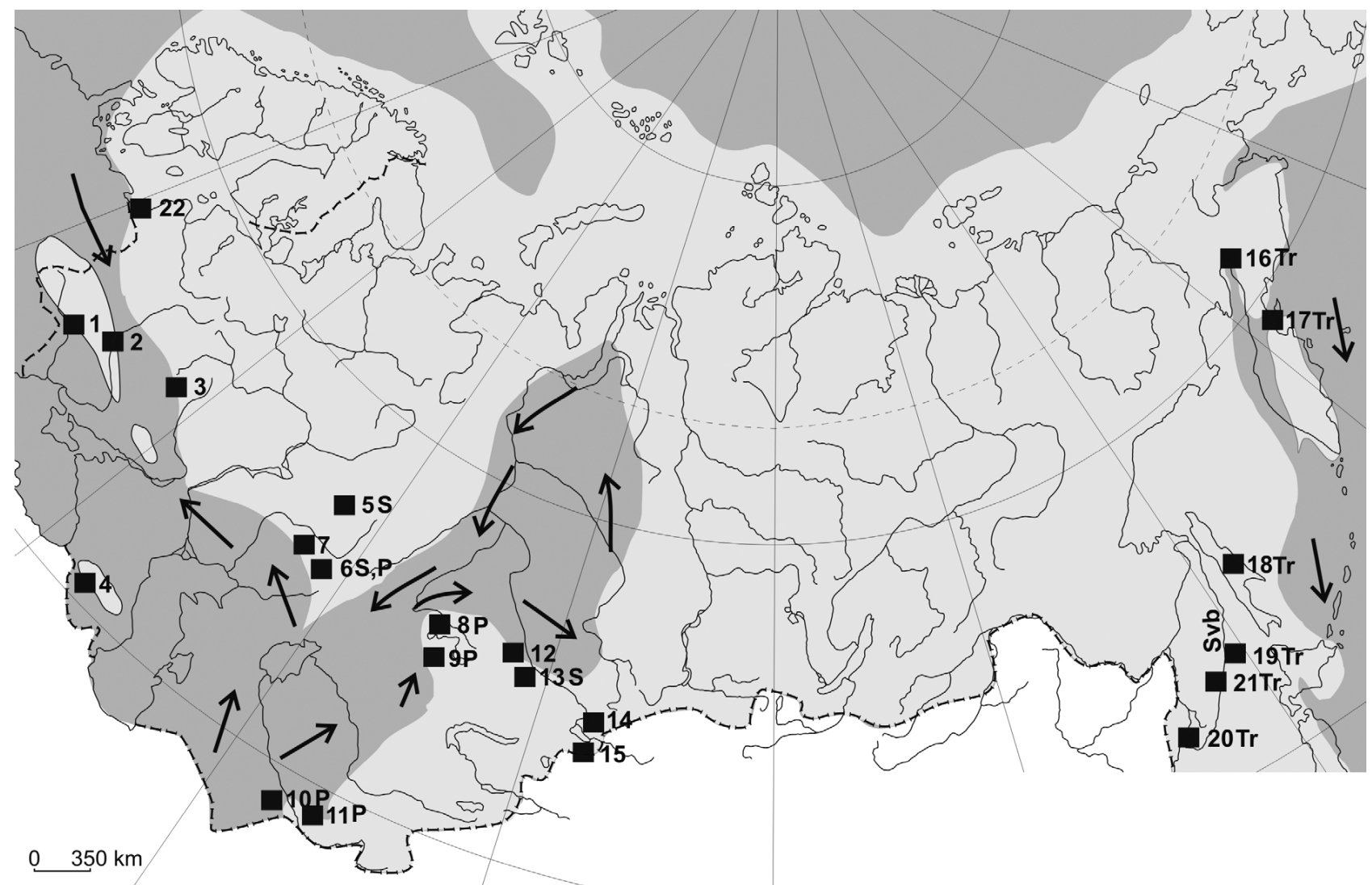

Figure 4. Late Lutetian-Bartonian. localities: 1 - Volyantschina (west of Kiev), 2 - Kiev (Lower Kiev Subformation) (N), 3 - Putivl (east of Kiev) (N), 4 - Akhaltsikhe (Georgia), 5 - Baky (Southern Ural) (S), 6 - Zharlykap (Or River Area, Southern Ural) (S, P), 7 - Or (Or River) (Southern Ural), 8 - Zhaman-Kaindy (Turgai District, Northern Kazakhstan) (P), 9 - Tortmolla (Turgai District, Northern Kazakhstan) (P), 10 - Akar-Cheshne (Western Badkhys, Turkmenia) (P), 11 - Er Oilan-Duz, Kushka district, Turkmenia) (P), 12 - Zhaman Tus (Irtysh River Area, North Western Kazakhstan), 13 - Takyrsor (Irtysh River Area, North Western Kazakhstan) (S), 14 - Tuzkabak (Zaissan Lake Basin), 15 - Kalmakpai (Zaissan Lake Basin) (Sargamyss Formation), 16 - Shestakovo (Penzhina Bay) (Tr), 17 - Podkagernaya (Western Kamchatka) (Irgirnin Formation) (Tr), 18 - Snezhinka (Western Sakhalin) (Upper Snezhinka Subformation), 19 - Sonye (Eastern Sikhote-Alin volcanic belt) (Tr), 20 - Rechnoi peninsula (northern of Vladivostok) ("Nadezhdinskaya" Formation) (Tr), 21 - Svetlovodnaya (Eastern Sikhote-Alin volcanic belt), 22 - Sambian peninsula, Prussian Formation, amber flora, Late Eocene, Svb - Sikhote-Alin volcanic belt.

Vassilevskaya, Rhus sp., Zizyphus spp., Tetracera sp., Melastomites sp., Diospyros sp. Palibinia is one of the dominant plants in this assemblage.

The Er Oilan-Duz flora (Kushka district, Turkmenia, Fig. 4, loc. 11) has the same stratigraphical position. The main components of this flora are Palibinia Korovin (several species), Rhus turkomanica (Krysht.) Korovin and Cinnamomum sp. Leaves of Rhus sp., Zizyphus and Diospyros were also found. Both of the Bartonian Turkmenian floras have small- and sclerophyllous leaves.

The age of some Turgaian Paleogene floras, e.g. the Tortmolla flora (Fig. 4, loc. 9) with Palibinia and Rhus turcomanica and the Zhaman-Kaindy flora (Fig. 4, loc. 8), originally dated to Early Oligocene (Zhilin 1989), has been revised. Zhilin (2005) changed his opinion and dated the Tortmolla flora to the Late Eocene. It is now possible to determine more precisely the stratigraphical position of the Tortmolla floristic layers. These layers overlap with
Middle Eocene marine deposits with rich dinocyst assemblage (N.I. Zaporozhets, personal communication). Fossil plants are concentrated in fossil soil horizons on a red-orange crust of weathering over marine deposits. The Oligocene clays with Chalicotherium (V.Y. Reshetov, personal communication) overlap and cross-cut the soil horizon. Therefore, the Tortmolla flora with Quasisequoia couttsiae, Palibinia, Rhus turcomanica, Leucothö̈, Echitonium, etc. is probably of Middle or Late Eocene age. The Tortmolla flora (only microphyllous) is a more xeromorphic type than the South Uralian and Cisirtyshian floras [see Fig. 2, loc. 5 - Smolino (with Oxycarpia), loc. 6 - Romankol, loc. 7 - Tykbutak; Fig. 3, loc. 5 - Karakol; Fig. 4, loc. 5 - Baky, loc. 6 - Zharlykap, loc. 7 - Or (All South Ural and Mugodzhary), loc. 8 - Zhaman-Kaindy, loc. 10 - Tortmolla (both of Turgai, North Kazakhstan)]. Judging according to the distribution of recent vegetation analogues of the Bartonian xerophytic plant assemblages, 
the precipitation was $200-600 \mathrm{~mm}$ per year, and the mean summer temperatures were $22-26^{\circ} \mathrm{C}$. Zonal types of vegetation north of the Peritethys coastal plane and southern coast of the West Siberian sea were sclerophyllous woodlands with different major components and rich in shrubs (like recent maquis) with narrow-leaved Ericaceae, Myricaceae, Fagaceae, Fabaceae, Myrtaceae, and sclerophyllous conifers.

\section{Late Eocene freshening of sea surface waters}

At this time, the partly isolated West Siberian marine basin opened to the Tethys. One of the main groups for biostratigraphic dating is organic-walled phytoplankton indicating a mid to late Eocene age at the Bartonian-Priabonian transition. At the beginning of the Late Eocene surface waters of the West-Siberian inner sea and Turanian sea on the North-Eastern Peri-Tethys margin were freshened after a continental bridge formed at the southern Arctic interrupting the Arctic/Tethys connection. This process was repeated several times. At the first stage layers with Pediastrum were formed there, in the second stage layers with Hydropteris indutus, and in the third stage layers with Azolla (megaspores and leaves) (Akhmetiev et al. 2004a, b; Akhmetiev \& Zaporozhets, personal observations). During the last century also impressions of leaves of Azolla vera Krysht. were recovered in the lower parts of the Chegan and Tavda formations (Bartonian-Priabonian transition) at many localities (Aral sea cliffs, Turgai and Irtysh areas in western Pavlodar escarpments of cuestas, West Siberia, and in South Siberian boreholes samples).

\section{Middle and Late Eocene, mixed deciduous and evergreen floras, Zaissan Lake Basin} (Fig. 4, localities 14, 15)

The Middle and Late Eocene floras of the Zaissan Lake basin are characterized by a mixture of evergreen and deciduous elements. The climate was more humid, but seasonal. Three localities of Bartonian age are known in this area: the Kalmakpai (Fig. 4, loc. 15) and Kiin-Kerish hills (same area as locality 8 in Fig. 2 with a continuous section from Late Paleocene to Oligocene) and the Tuskabak depression area (Fig. 4, loc. 14) around the Zaissan Lake. Plant remains are concentrated in variegated clays between two red weathering clayey crusts. The main components of the Mid to Late Eocene Kiin-Kerish flora (I.A. Iljinskaya and Akhmetiev, personal observations) are "Hibiscus" neuburgae, "Hibiscus" kalmakpaica, Populus kryshtofovichii, Fabaceae (leaves and fruits), rare Comptonia, small-leaved Ulmus, Liquidambar, Celtis, Zelkova, Magnolia, and Ailanthus. The richest is the Sargamyss Formation flora in the
Kalmakpai area. It includes in addition Salvinia natanella, Craigia, Lindera vassilenkoi, and Ungnadia. The flora of the Tuskabak depression includes also Dryophyllum, Nitophyllites and Alnus.

The Late Eocene flora of the Turanga Formation (Kiin-Kerish hill) was studied by Iljinskaya (1963, 1986) and Akhmetiev (1985). Thin-bedded light yellow clays and thin sands (22-25 m) overlaid by variegated deposits with the Bartonian flora include three floristic layers of the Turanga flora $(9,12$ and $20 \mathrm{~m}$ above the base of the Turanga Formation). Late Eocene swamp rhinoceros Zaissanamynodon borissovii and Kiinkerishella zaissanica (Arctocionidae) were found $2 \mathrm{~m}$ above the base of this section (7 $\mathrm{m}$ lower than the first floristic layer). In the lower floristic layer Salvinia mildeana, Nelumbo, Zingiberites borealis are dominant. "Hibiscus" neuburgae and Ulmus are rarer.

The next floristic layer ( $3 \mathrm{~m}$ further above) is formed by clays. This riparian assemblage consists of Alnus, Ulmus, Populus arnaudii, "Hibiscus" neuburgae, Zelkova zelkovifolia, rarely Lindera sp., Myrica sp., Leguminosae spp. (leaves and fruits), Dryophyllum spp., Sterculia sp., Eucalyptus sp. and Apocynophyllum sp. Several leaf beds were formed by Ulmus sp. and "Hibiscus" neuburgae.

The upper floristic horizon is formed by a lens of white clay just below the red soil horizon (first stage of originating crust of weathering). Fossil plants are sclerophyllous, of middle size, some also narrow-leaved. The following elements were determined: Dryophyllum curticellense, D. dewalquei, D. krystofovichii, Myrica acuminata, Myrica cf. lignitum, Taxodium dubium, Lindera vassilenkoi, Zelkova zelkovifolia, Ampelopsis schischkinii, Fraxinus, Astronium ninae, Craigia, etc.

\section{Later Paleocene and Eocene floras in the Western Pacific Margin}

The majority of the Western Pacific Paleogene plant localities are situated in intermontane coal bearing deposits in depressions, some of them occupying vast areas (e.g., the Zeya-Bureya sedimentary basin, Amur River area) in marine coastal zones, and in sedimentary tuffaceous beds of the West Pacific volcanic belts.

The main characteristics of the East Asian floras and climate are principally different from contemporaneous floras and climate in Central and Western Russian Eurasia at middle latitudes. The East Siberian and Far East Paleogene floras belong to the Boreal realm. The composition of East Asian floras was influenced by a cold current running along the eastern coast from Beringia through Kamchatka, Sakhalin to Japan. The stability of this current was maintained by the long existing Bering Land Bridge. 


\section{Early Eocene floras of the high latitude} Siberian Platform (Fig. 2, localities 9-11)

The Early Eocene climate at the northern margin of the Siberian platform was similar to the climate of the polar sea, where the surface-water temperature reached $+20{ }^{\circ} \mathrm{C}$ (Backman et al. 2006). It was frostless or with episodic short cold winters. This is confirmed by some localities that are nowadays situated within the Arctic Circle, north of $70 \mathrm{~N}$ (grabens on the lower course of the Lena River (Fig. 2, locs 9, 10) and Lake Tastakh (Fig. 2, loc. 11) in the Yana and Indigirka interfluve). These floras contain remains of gymnosperms (Ginkgo, Pinaceae, Taxodium, Metasequoia, etc.), both deciduous broadleaved trees (Trochodendroides, Platanaceae, Ulmaceae, etc.) and thermophilic southern migrants, such as Myrtaceae and Liquidambar represented by leaves and reproductive organs (Ozerov et al. 2006), leaves of Magnolia, Palmae (pollen), Loranthaceae (pollen), and Hamamelidaceae (Kulkova 1973).

\section{Early Paleogene floras of North East Russia} (Fig. 2, localities 12-14, Fig. 3, locality 11), Sakhalin (Fig. 1, locality 8) and South Primorie (Fig. 2, localities 16, 17)

The early Paleogene floras of northern Russia, like the preceding Late Cretaceous flora, were broad-leaved and existed under conditions of limited day-light during short winter days within the Arctic Circle. L.Y. Budantsev (1983, 1986, 2006) described three stages of floral evolution in the Early Paleogene of the western Kamchatka Peninsula (which he referred to as the Beringian Province of the Boreal Realm), (i) Khulgun (Paleocene), (ii) Tchemurnaut (Fig. 2, loc. 13) (Early and Early Middle Eocene) and (iii) Irgirnin (Late Eocene according to Budantsev, Middle-Late Eocene transition according to Zaporozhets et al. (2006) based on a dinoflagellate assemblage at the base of the Ratygin Formation which conformably overlies the plant-bearing Irgirnin Coal Formation).

The Khulgun-type flora (Palana locality, near Snatol) (Fig. 3, loc. 11) was rich with more than 70 species two thirds of which appear for the first time (Budantsev 2006). These include Osmundastrum, Dennstaedtia, Ginkgo, Magnolia, Lindera, Tetracentron, Betula, Corylus, Alnus, Carpinus, Myrica, Juglans, Pterocarya, Acer, Hydrangea and others. The same type of Paleocene flora is known on Sakhalin (Kama beds) containing Taxodiaceae, Ulmaceae, Craigia, Trochodendroides arctica and others (Kodrul 1999). The Tchemurnaut stage coincides with the Early Eocene major global warming. The Tkapravajam Formation flora (Budantsev 2006) includes at least $40 \%$ entire-margined leaves and a high diversity of thermophilic plants reaching 64\%. Among them are Lygodium, Ocotea, Cinnamomophyllum, Corylopsis, Platycarya, Camellia, Byttneria, Dombeya, Myrtophyllum, Leguminosae (fruits and leaves), and others. Leaves of Sabal were discovered between the capes Rebro and Kengi (Fig. 2, loc. 14). A partial specimen of Sabal (lacking the rachis) was found by V. Volobuyeva in levels of the same age south of the mouth of the Anadyr River (North Koryakia) (Fig. 2, loc. 12). Unfortunately the specimen is now lost so the record is treated as ?Sabal on the map. During the Middle Eocene cooling most thermophilic plants disappeared and the Irgirnin flora corresponds to a temperate mesophilic type, with numerous conifers (Pinus, Abies, Larix, Metasequoia, Taxodium, Cryptomeria, Cunninghamia, Sciadopitys, etc). The appearance of Fagus, Castanea and some other modern genera, analogous to the Irgirnin flora, was recorded by the author from the Ust - Penzhina Formation (Penzhinskaya Bay, South Koryakia), in the central part of the Rarytkin Ridge (North Koryakia) (for location see Fig. 1, loc. 11 an area with both Danian and Early Eocene floras). T.M. Kodrul described a similar flora from Sakhalin (Kama River beds, Fig. 1, loc. 8) (Kodrul 1999).

In Northern Vladivostok an Early Eocene flora was found at the base of coal-bearing deposits on the Rechnoi peninsula (Uglovaya Formation, Taurichanka coal-field, Fig. 2, loc. 16). This is a typical Metasequoia-Trochodendroides-Platanaceae assemblage (Akhmetiev 1993). Most of the plants are concentrated in coal-bearing sandstones and silts (middle part of Uglovaya Formation). In addition to these dominants Magnolia sp., Pterocarya sp., Zelkova kushiroensis Oishi \& Huzioka, Nelumbo nipponica Endo, Hamamelis sp., Liquidambar sp., Rhus sp. and Plafkeria sp. were identified.

In eastern Vladivostok in the Maikhe coal-bearing field (Fig. 2, loc. 17) some thermophillic plants [evergreen Fagaceae, Lauraceae and Leguminosae (Akhmetiev 1993)] were found at the base of the Uglovaya Formation.

\section{Eocene warm temperate floras of the Russian Far East}

The Far East flora remained warm-temperate, mesophilic and deciduous till the Late Eocene and retained some Early Paleogene morpho-genera like Trochodendroides or Fagopsis. Only during global warming at the Paleocene/Eocene boundary and in the Early Eocene did some evergreen immigrants invade into high latitudes. At that time, palms (Sabal) reached Western Kamchatka and Koryakia (as far as to $64^{\circ} \mathrm{N}$ ). The boundary between the Boreal and Tethys realms was shifted northwards by $8-10^{\circ}$ in the Far East (Akhmetiev et al. 2002, Budantsev 2006). 


\section{Eocene subtropical Raichikha flora (Fig. 2 locality 15, Figs 5-7)}

The Lower Paleogene deposits of the Zeya-Bureya sedimentary basin include two types of floras: warm-temperate Tsagayan (Paleocene) (see section on Danian floras) and Raichikha (Eocene). The Early Eocene flora of the Raichikha coal-field $\left(50^{\circ} \mathrm{N}\right)$ has a distinctive composition, with typically subtropical elements and including various evergreen plants (Figs 5-7). This flora was studied by T.N. Baikovskaya (1950). Later A.N. Krystofovich (1952) noticed the unusual composition of the flora. M.A. Akhmetiev (1969, manuscr.), V.V. Fedotov (1983, doctor thesis), and A.M. Kamaeva (1990) described many new taxa. The Raichikha and preceding Tsagayan floras have very few elements in common (except for some ferns, Taxodium, Porosia and Platanaceae). The Tsagayan-type flora could not be an ancestral assemblage to the Raichikha flora. The Raichikha flora includes southern elements which might have migrated from the low latitudes during the Early Eocene warming. Modern analogues of the Raichikha flora are widespread through South China and also Japan $\left(30^{\circ} \mathrm{N}\right)$. The Raichikha flora lacks palms, but it is characterized by diverse ferns, various evergreen and deciduous angiosperms. This flora is composed of one member of Hepaticopsida, one Equisetum, 10 ferns, one conifer, more than 70 species of dicots (of which $44.6 \%$ have entire margined leaves) and 6 monocots. Betulaceae and Trochodendroides were not recovered.

Especially in aquatic and helophytic assemblages the Raichikha flora is similar to that of the Paleocene and Early Eocene Zaissan Lake basin (South East Kazakhstan) (Fig. 2, loc. 8). The Raichikha assemblage includes (Figs 5-7) Marchantites, Cyclosorus, Osmunda, Woodwardia, Salvinia, Regnellidium, Taxodium, Nelumbo, Nuphar, Hibiscus, Limnobiophyllum, Zingiberopsis, Peltandra, Typha, Lauraceae and Fabaceae along with Rhamnaceae (Guoania, Ziziphus). The Raichikha flora occupied more elevated habitats too, accompanied by ferns, such as $L y$ godium and Anemia. The flora includes many evergreen plants (Magnolia, Ocotea, Neolitsea, Ficus, some Fabaceae, Myrtophyllum, Delavaya, etc.) (see Figs 5-7).

The Raichikha flora arose in the northern part of the subtropical realm of Eastern Eurasia. In the Early Eocene the Raichikha flora suggests that the northern boundary of the subtropical zone migrated at least $20^{\circ}$ further north relative to its present position. The Early Eocene climate was subtropical monsoon (summer wet). This is confirmed for the Raichikha Formation by active kaolinization.

\section{Late Ypresian and Lutetian floras of the North-Western Pacific coast (Fig. 3, localities 9-11), Sakhalin (Fig. 3, localities 12-14), Primorie (Fig. 3, locality 15)}

The floras of the localities of the North-Western Pacific: Circus Mount (North Koryakia, Fig. 1, loc. 9) (Akhmetiev 1993), Kangpil Cape (Penzinsky Bay, Fig. 3, loc. 10) (Akhmetiev 1993) and Snatol River (Western Kamchatka, loc. 11) (Budantsev 1997, 2006) are similar and represent typical Late Ypresian-Early Lutetian assemblages with ferns (Osmunda macrophylla Penhallow, Dennstaedtia americana Knowlt., Lygodium coloradense Knowlt.), Ginkgo kamtschatica Budants., Metasequoia occidentalis (Newb.) Chaney, Taxodium tinajorum Heer, Glyptostrobus europaeus (Brongn.) Heer, Magnolia basicordata Fotjanova \& O. Lavrenko, Trochodendroides arctica (Heer) Berry, Nyssidium arcticum (Heer) Iljinskaya, Cocculus ezoanum Tanai, Nordenskioldia borealis Heer, Populus microdentata Budants., P. celastrophylla (Baikovskaya) Sycheva, Carpinus ex gr. C. japonica Blume, Alnus kushiroensis Tanai, Alnus sp., Fagopsis sp., Dryophyllum sp., Platanus cf. P. newberriana Heer, Craigia oregonensis (Arn.) Kvaček, Bůžek \& Manchester, "Pterospermites" auriculaecordatus Hollick, Archeampelos acerifolia (Heer) McIver \& Basinger and others.

The flora from Due village (North-Western Sakhalin, Fig. 3, loc. 12) was first described by Kryshtofovich (1936) and Borsuk (1956). The fossils belong to the Conglomerate Formation, but mainly the Lower Due Formation (conglomerates, sandstones, silts and coal). The main components of this flora are Osmunda sachalinensis Krysht, Lygodium asiaticum Borsuk, Ginkgo adiantoides (Ung.) Heer, Metasequoia occidentalis (Newb.) Chaney, Taxodium dubium (Sternb.) Heer, Glyptostrobus europaeus (Brongn.) Ung., Trochodendroides arctica (Heer) Berry, various Amentiflorae (Populus celastrophylla Baikovskaya \& Sycheva, Myrica ovalifolia Borsuk, Castanea longifolia Borsuk, Quercus spp., Alnus onorica Borsuk

Figure 5-7. Plant macrofossils showing the distinctive nature of the Early Eocene subtropical flora from Raichikha (Zeya-Bureya sedimentary basin, Amur River Area) (coll. No. 3816, Geological Institute RAS).

Figure 5. A, B, F, K-Anemia elongata (Newberry) Knowlton: A - No. 3816/36 (×2), 2 - No. 3816/128 (×2), F-No. 3816/426 (×2), K-No. 3816/371 $(\times 2)$. $・$ C - Filices sp., No. $3816 / 105(\times 2.5)$. D , E - Taxodium dubium (Sternb.) Heer: D - No. $3816 / 59(\times 1)$, E - No. $3816 / 165(\times 2) . \bullet$ G - Guoania grubovii Fedotov, No. 3816/1996 (× 1). • H, L - Salvinia praeaculeata Berry: H - No. 3816/256 (× 5), L - No. 3816/27(× 5). • I, M - Ziziphus raitschichensis Fedotov: I - No. $3816 / 469(\times 1)$, M - No. 3816/113 (× 1). J - Ocotea beringiana Budants., No. $3816 / 345(\times 1)$. N - Morus sp., No. $3816 / 150(\times 1)$. 
Mikhail A. Akhmetiev • Paleocene and Eocene floristic and climatic change in Russia and Northern Kazakhstan
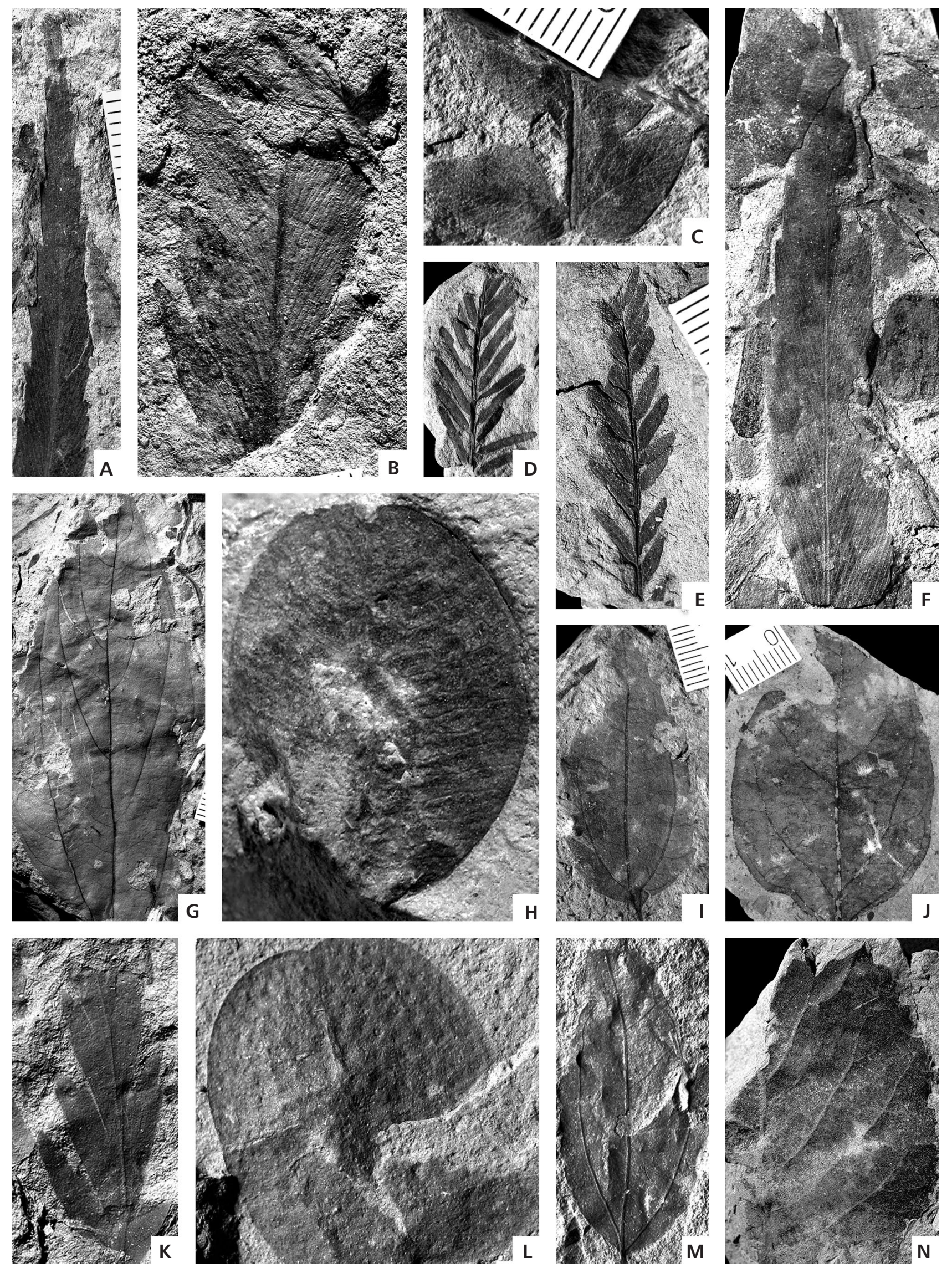
and others), Magnolia kryshtofovichii Borsuk, Platanus spp., Liquidambar europaea A. Braun, Vitis sachalinensis Krysht. and others (Sorbaria, Craigia, Zizyphus, Rhamnus, Viburnum, Rosaceae, Daphne, Vaccinium ). This assemblage consists of more then 40 species.

Two other floras (Western Sakhalin, Lower and Middle Snezhinka Subformations, Fig. 3, loc. 13 and South-Eastern Sakhalin, Naibuti Formation, Fig. 3, loc. 14) were studied by Sycheva (1977), Akhmetiev (1993) and Kodrul (1999). Both floras are the same age, probably Late Ypresian-Lutetian, but they are distinguished by ecological factors. The ferns are few (Osmunda sachalinensis Krysht., Onoclea hesperia R.W. Brown), gymnosperms are dominant, especially Ginkgo adiantoides (Ung.) Heer, Glyptostrobus europaeus (Brongn.) Heer, Metasequoia occidentalis (Newb.) Chaney, Taxodium dubium (Sternb.) Heer, more rarely Pseudolarix, Sciadopitys, Pinaceae and Cupressaceae are almost absent. The main components of angiosperms are Trochodendraceae, Platanaceae, Fagaceae, Betulaceae, Salicaceae, Ulmaceae: (Trochodendroides arctica (Heer) Berry, Nordenskioldia borealis Heer, Platanus acutiloba Borsuk, P. mabuti Oishi \& Huzioka, P. zhuravlevii Medjul., Castanea longifolia Borsuk, C. sachalinensis Kodrul, Fagopsis nipponica Tanai, Alnus ezoensis Tanai, A. hokkaidoensis Tanai, A. kushiroensis Tanai, Carpinus kushiroensis Tanai, Populus budantsevi Ablaev, P. celastrophylla (Baikovskaya) Sycheva, $P$. gigantophylla Budants., Ulmus ezoana (Oishi \& Huzioka) Kodrul, U. harutoriensis Oishi \& Huzioka, Zelkova kushiroensis Oishi \& Huzioka). Tiliaceae are represented by Craigia oregonensis (Arnold) Kvaček, Bůžek \& Manchester, Plafkeria basiobliqua (Oishi \& Huzioka) Tanai, various Rosaceae, Aceraceae, Anacardiaceae, Vitaceae (Crataegus sp., Rubus fretalis Borsuk, Acer cf. kushiroanum Tanai, Acer cf. palaeoplatanoides Endo, Acer spp. (fruits), Cotinus sp., Rhus angustifolia Kodrul, Vitis sachalinensis Krysht., Vitis spp.) and others (more than 100 species). More warmer elements of these floras are Byttneria iizimae Tanai, Kleinhovia basitruncata (Oishi \& Huzioka) Tanai, Ficus spiculifolia Nagai, Phytocrene sp. A more ancient element of these floras is Archeampelos acerifolia (Heer) McIver \& Basinger.

The flora from the lower part of the coal-bearing Uglovaya Formation (Artjem coal-field) (Fig. 3, loc. 15) consists of typical Early and Middle Eocene components (Ginkgo, Taxodiaceae, Trochodendroides, Platanaceae, Ulmaceae, ancient Amentiferae). There are more often
Hamamelidaceae (Hamamelis, Fothergilla, Corylopsis), Lauraceae (Sassafras, Daphnogene) and Magnoliaceae (Akhmetiev 1993).

Late Lutetian-Bartonian warm temperate to temperate floras of the North-Western Pacific coast (Fig. 4, localities 16, 17), Sakhalin (Fig. 4, locality 18), South Primorie (Fig. 4, locality 20)

On the North-Western Pacific coast there are several localities. Shestakovo (Fig. 4, loc. 16) on the south coast of Penzhina bay is situated between the mouth of the Shestakovo River and Lovaty Creek. Plant fossiliferous strata contain interbedded silts and siltstones, coals and coaly silts, rare sandstones $(300 \mathrm{~m})$, thin coal and coaly clays lenses and diatomitic clays with marine diatoms, probably Middle Eocene. Coaly clays and silts include fossils (leaves, seeds, fruits, sometimes conifer woods).

This flora was studied by Kryshtofovich (1958), Ablaev (1985), and Akhmetiev \& Bratsteva (1989). The authors collections include more than 20 species - typical elements of the Middle Eocene North-East Asia floras: Equisetum arcticum Heer, Dennstaedtia americana Knowlt., Osmunda macrophylla Penh., Ginkgo ex gr. adiantoides (Ung.) Heer, Picea sp. (seeds), Pinus sp. (leaves), Pinus sp. (seeds), Pseudolarix sp. (bractea), Taxodium tinajorum Heer, Metasequoia occidentalis (Newb.) Chaney, Sequoia sp., Glyptostrobus europaeus (Brongn.) Heer, Cupressaceae gen., Magnolia praekobus Budants., Trochodendroides arctica (Heer) Berry, Nyssidium arcticum (Heer) Iljinskaya, Alnus protophylloides Budants. \& Golovneva, Myrica beringiana Budants., Juglans pogozheviii Chelebaeva, Craigia oregonensis (Arnold) Kvaček, Bůžek \& Manchester, Acer sp., Aesculus magnifica (Knowlt.) Iljinskaya, Archeampelos acerifolia (Newb.) McIver \& Basinger [= "Acer" arcticum (Heer) R.W. Brown], Cissites ochotensis Krysht.

The Irgirnin assemblage is very similar to that from Shestakovo. L.Y. Budantsev described the flora from Podkagernaya Bay on the coast (Fig. 4, loc. 17), but it is probably younger, late Middle Eocene-(?)Late Eocene. It includes Cercidiphyllum intermedium Budats., Ulmus compacta Fotjanova, Liquidambar brevilobata Budants., Fagus napanensis Fotjanova, Castanea kamtschatica Fotjanova, Juglans protocinerea Iljinskaya \& Budants. Most of the components are the same as Shestakovo (Equisetum arcticum, Dennstaedtia americana, Ginkgo ex gr. adian-

Figure 6. A, J-L - Ocotea beringiana Budants.: A - No. $3816 / 571(\times 1.2), \mathrm{J}-3816 / 179(\times 1)$, K - No. $3816 / 387(\times 1)$, L - No. $3816 / 406(\times 1)$. • B - ?Tilia sp., No. 3816/486 (× 1). • C - Lindera rajczichensis Fedotov, No. 3816/215 (× 1). • D - Neolitsea rajczichensis Fedotov, No. $3816 / 443(\times 1)$. • E, H - Urticaceae gen. et sp. indet.: E - No. 3816/192 (× 1), H - No. 3816/201 (× 1). • F, I - Hibiscus sp.: F - No. $3816 / 276(\times 1.5)$, I - No. $3816 / 209$ $(\times 1) \cdot \bullet \mathrm{G}-$ Zingiberopsis magnifolia (Knowlton) Hickey, No. 3816/101 $(\times 1)$. 
Mikhail A. Akhmetiev • Paleocene and Eocene floristic and climatic change in Russia and Northern Kazakhstan
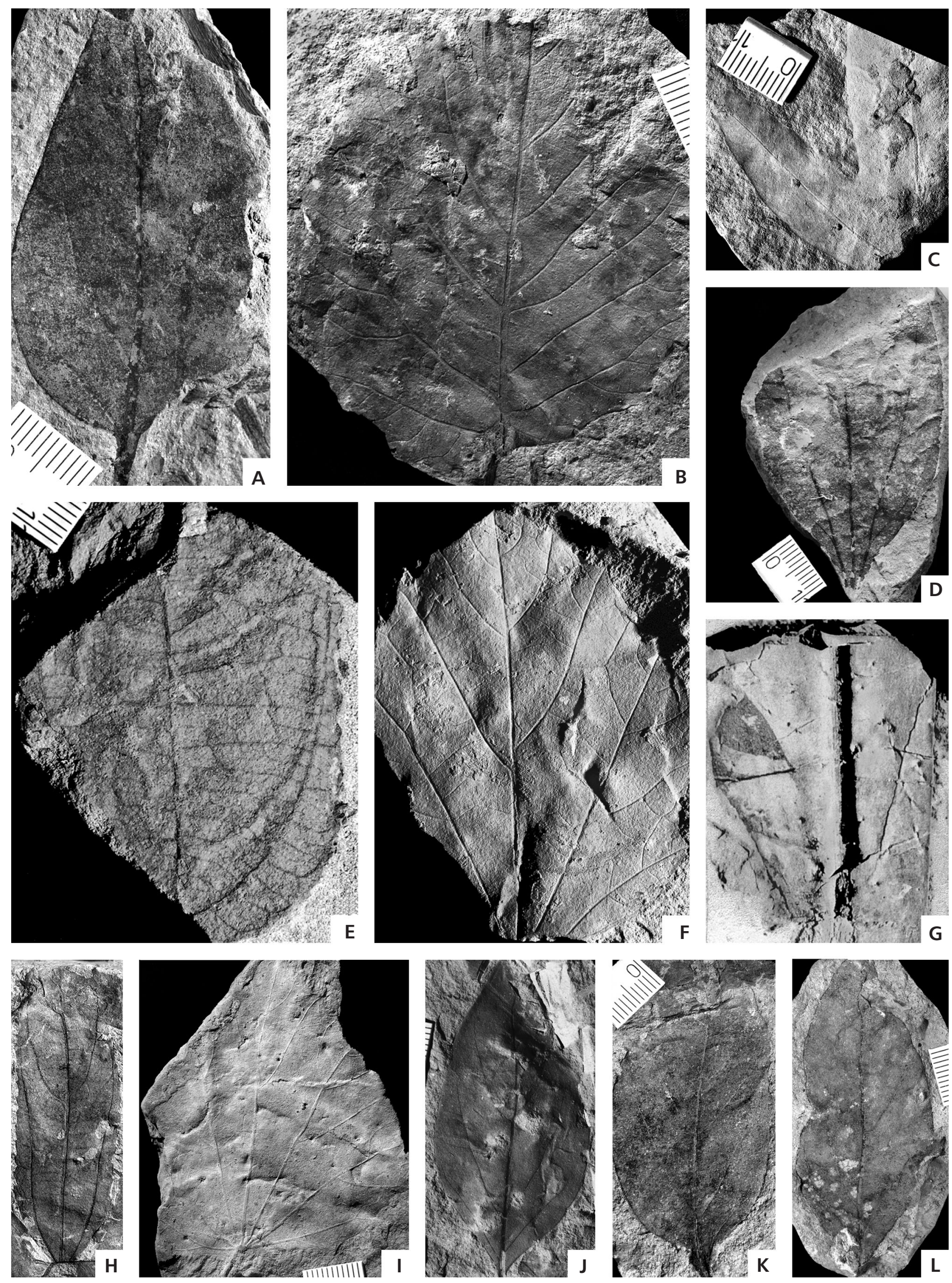
toides (Ung.) Heer, Metasequoia occidentalis, Glyptodtrobus europaeus, Trochodendroides ex gr. arctica, Alnus protophylloides (Budantsev 1997).

The late Middle Eocene floristic section of Middle Sakhalin, situated near Uglergorsk town (Snezhinka River basin) (Fig. 4, loc. 18) is very important. The late Middle Eocene Upper Snezhinka subformation represents coals, coal bearing silt and siltstones and rare sandstones $(300 \mathrm{~m})$. The fossil leaves and fruits are smaller in size than in the Kamchatka-Koryakia region, but the taxonomic composition is similar (Akhmetiev 1993, Kodrul 1999). T.M. Kodrul described 36 species, mostly warm-temperate elements. There are 6 ferns: Osmunda, Dennstaedtia, Dryopteris, Lastrea, Onoclea, Woodwardia. Conifers (not more then $10 \%$ specimens) are represented by Pseudolarix, Glyptostrobus, Metasequoia, Taxodium. Angiosperms (more than 20 species) include Trochodendroides arctica (Heer) Berry, Nyssidium arcticum (Heer) Iljinskaya, Platanus sp., various Amentiferae (Alnus ezoensis Tanai, A. ishikariensis Tanai, Alnus spp. (leaves and catkins), Betula sp., Corylus palaeomaximovicziana (Endo) Tanai, Myrica vindobonensis (Ett.) Heer, Populus celastrophylla (Baikovskaya) Sycheva, P. gigantophylla Budants, $P$. grandifolia Endo), some Ulmaceae and Rosaceae, Archeampelos acerifolia (Heer) McIver \& Basinger, Acer sp., Euonymus denticulata Kodrul and others. Some of the species was described by Tanai $(1967,1970)$ from Hokkaido.

The Middle Eocene floristic layers were studied on Rechnoi peninsula (north of Vladivostok) (Fig. 4, loc. 20). The terrigenous Nadezhdinskaya Formation (predominantly silts and siltstones with rare sandstones) is subdivided into three members (Akhmetiev 1993). The Lower Member contains rare fossil plants [Dryopteris sp., Metasequoia occidentalis (Newb.)] Chaney, Ulmus sp., Populus iljinskajaa Akhmetiev, Platanus sp., Lauraceae gen. The Middle Member has a richer floristic assemblage. It includes Metasequoia and Trochodendroides (dominants), Magnolia sp., Alnus cf. protohirsuta Endo, Ostrya sp., Juglandaceae gen., Ulmus ex gr. longifolia Ung., Zelkova kushiroensis Oishi \& Huzioka, Hamamelis sp., Leguminosae gen., Cinnamomum sp., Cedrela sp., Plafkeria sp. The Upper Member is the main floristic horizon. The dominant elements are Metasequoia occidentalis (Newb.) Chaney, Populus iljinskajae Akhmet., Zelkova zelkovaefolia (Ung.) Bůžek \& Kotlaba, Platanus aceroides Goepp., Laurophyllum sp. The rarer elements are Trochodendroides arctica (Heer) Berry, Nordenskioldia borealis Heer, Liquidambar miosinica $\mathrm{Hu} \&$ Chaney, Cinnamomum sp. and Plafkeria sp. The rarest elements are Osmunda sakhalinensis Krysht., Ginkgo adiantoides (Ung.) Heer, Pinus sp., Taxodium dubium (Sternb.) Heer, Zingiberaceae gen., Magnolia sp., Carpinus ex sect. Eocarpinus, Celtis sp., Leguminosae gen., Hamamelis kushiroensis Tanai, Vitis sp., Tilia eojaponica Endo, Mallotus hokkaidoensis Tanai, Rhus sp., Fraxinus sp. The floristic assemblage is characterized by small leaves (up to $3-5 \mathrm{~cm}$ long) linked to a winter wet climate.

\section{Paleocene and Eocene floras of the Sikhote-Alin volcanic belt (Fig. 1, localities 7-10, Fig. 4, localities 19, 21)}

The Sikhote-Alin volcanic belt is limited to the east by the Tatarian strait and the coast of Japan. The belt experienced two stages of volcanic activity: Senonian-Paleocene and late Middle Eocene-Early Miocene. These volcanic sequences are separated by gaps. In the southern part of the volcanic belt sedimentary lenses with floras accumulated in intermontane valleys and small lake depressions above the sea-level (Takhobe and Zerkalnaya localities, Fig. 1, locs 9, 10). In the northern part (Malo-Mikhailovka locality, Fig. 1, locs 7, 8) fossiliferous layers accumulated in swampy depressions near volcanoes. Their Danian or Selandian age is based on radiometric data and comparisons of these floras with the Tsagayan floras in the Zeya-Bureya depression. Most typical common elements are Ginkgo, Taxodium, Cupressinocladus, Trochodendroides, Nyssidium, Nyssa, Tiliaephyllum, platanoids etc. Elements which differ from the typical Tsagayan flora are diverse conifers, various Amentiferae e.g., Alnus and Betula (fruits and leaves) (Takhobe and Zerkalnaya localities), Corylites and Palaeocarpinus (Malo-Mikhailovka locality), Juglandaceae and Fagopsis (Takhobe). Ulmus furcinervis is a common component of the Kivda flora (Bureya River Area, Fig. 1, loc. 5 same locality as Tsagayan flora) and the main dominant in the Takhobe and Zerlalnaya floras. Sorbus and Davidia also occur there. These Paleocene assemblages typically have leaves and fruits of large size. Lignites and coaly clays at the Malo-Mikhailovka locality accumulated in swampy depressions and small river systems and yielded Muscites, Equisetum, Onoclea, Dennstaedtia, Asplenium, Ginkgo, Fokieniopsis, Cryptomerites, Amurocyparis, Palaeocarpinus, Corylites, Trochodendroides, Trochodendrocarpus.

The oldest Eocene floras of the Eastern Sikhote-Alin basaltic belt are found on the north coast at Sonye Bay (Fig. 4, loc. 19), $200 \mathrm{~km}$ south of Sovietskaya Gavan town. Thin ash lenses between basaltic flows (Kizi Group) contain different gymnosperms (more than $50 \%$ of specimens) [Ginkgo, Pinus, Picea, Metasequoia, Taxodium, Glyptostrobus, Cryptomeria, Metasequoia, Taxodium, Cunninghamia, Torreya, (?)Cupressaceae, (?)Podocarpus and others]. Angiosperms are represented by Quercus ex gr. Dentatae, Fagus sp., Acer ezoanum Oishi \& Huzioka and 
Mikhail A. Akhmetiev • Paleocene and Eocene floristic and climatic change in Russia and Northern Kazakhstan
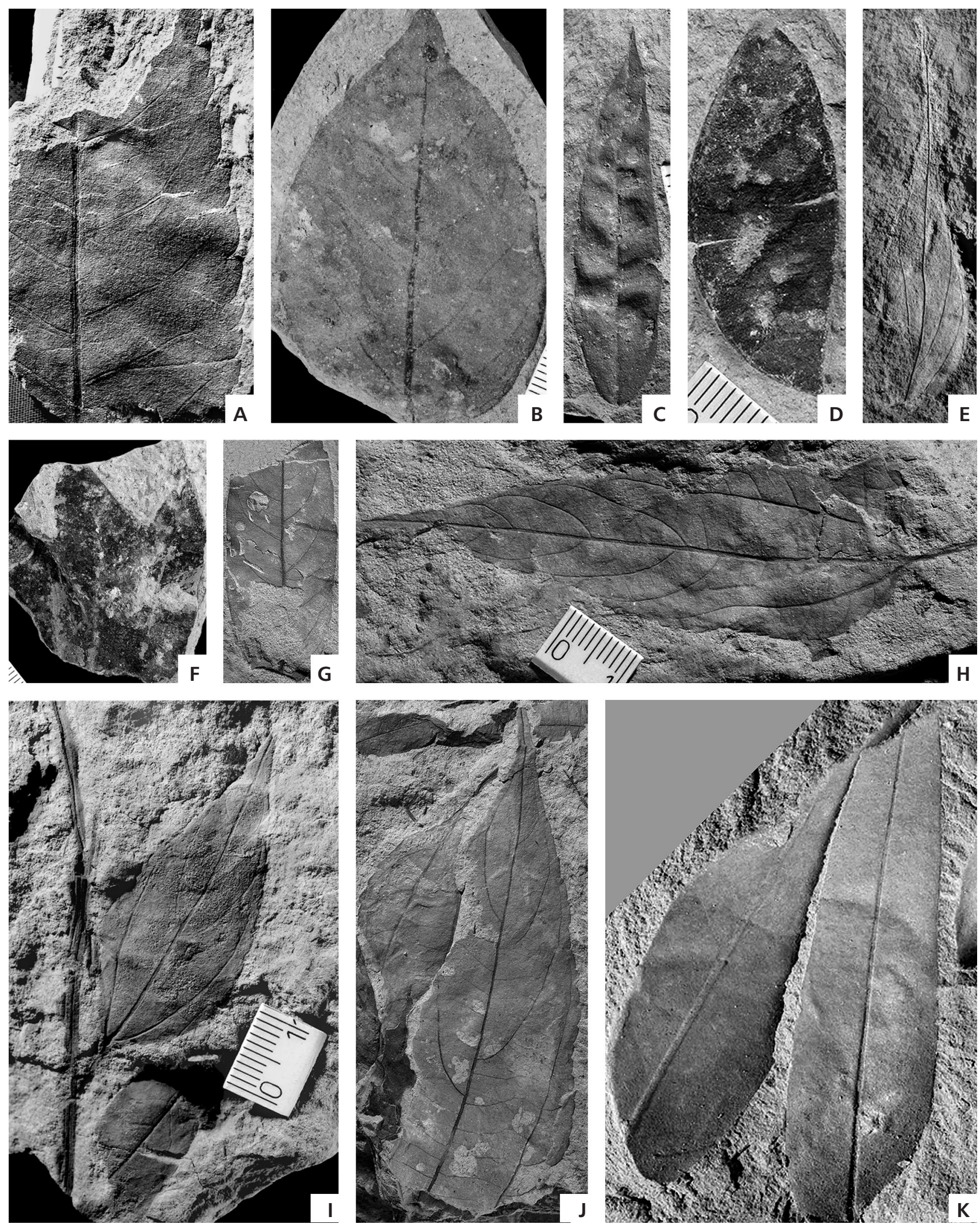

Figure 7. A - Rhus sp., No. 3816/70 (×2). B - Ficus schimperi Lesq., No. $3816 / 417(\times 1) \cdot \bullet$ C - Delavaya fraxinifolia Fedotov, No. $3816 / 287(\times 2)$.

-D - Leguminocarpon sp. (associated with leaves of Stenolobium), No. 3816/389 (× 3). E, H, I, J - Celtis sp. E - No. 3816/139 (× 1), H - No. 3816/140 (× 1), I - No. $3816 / 178(\times 1)$, J - No. $3816 / 144(\times 1) \cdot \bullet$ F - Lindera raiczichensis Fedotov, No. $3816 / 372(\times 1) \cdot \bullet \mathrm{G}-$ Stenolobium sp., No. $3816 / 6(\times 1)$.

$\cdot \mathrm{K}$ - Leguminosites raiczichensis Fedotov, No. 3816/251a ( $\times 3)$. 
others. The abundance of conifers is connected with an upland habitat of the assemblage (Akhmetiev 1993).

A very similar flora was described by Akhmetiev (1993) from near the Svetlovodnaya River valley (Fig. 4, loc. 21). This flora contains Ginkgo, Metasequoia, Trochodendroides, Fagopsis, Ulmaceae gen., Craigia, Plafkeria, Vitis, Acer and others.

\section{Conclusions}

The Paleogene floristic evolution of Russia provides a reliable proxy for coeval climatic trends and stages. The floras were mainly determined by the paleogeographic configuration and current dynamics of the N-S and W-E trending systems of epicontinental seas and straits that connected the Arctic, Tethys and Atlantic Oceans. The global regression at the Maastrichtian-Danian transition resulted in the dewatering of Northern Central Eurasian seas and straits and was accompanied by migration of deciduous mesophilic warm temperate Tsagayan ecotype flora from Eastern Asia to East and North Kazakhstan and Siberia. During the Late Paleocene and Early Eocene North Central Eurasia was included in the paratropical humid climate zone. The main fossil plant localities (Kamyshin, Romankol etc.) correspond to a typical paratropical Gelinden-type flora. At the PETM episode and Early-Middle Ypresian some evergreen plants migrated and reached the Arctic Siberian Coast. Thermophilic plants migrated to the north. Sabal, Myrtaceae and Lauraceae reached Koryakia, North Western Kamchatka. Some subtropical plants were found near the recent Polar circle. The subtropical Raichikha-type Flora lost temperate elements and, by ecological and climatic types, it is more similar to the Recent flora of South-West and South China.

In the Late Ypresian and Lutetian the latitudinal straits connecting the West Siberian Sea and the Turgai strait with the Atlantic were reduced. As a result the subtropical monsoon climate spread over North Central Eurasia. A subtropical flora, with dominant Fagaceae (especially Castanopsis) and Lauraceae, was developed. In the Bartonian the West Siberia sea was isolated from the Polar Basin, but a connection with Tethys still existed. The paleogeographic evolution was accompanied by a climatic change from summer-wet conditions to a winter-wet climate, which is similar to the recent Mediterranean subtropical climate characterized by dry and hot summers. Palibinia, Leucothö̈, small sclerophyllous Fagaceae and other xeromorphic angiosperms together with Quasisequoia were the main components of this North-Central Eurasia flora. Paleocene and Eocene warm-temperate mesophilic deciduous floras were distributed at the West Pacific periphery.

\section{Acknowledgments}

The author thanks M. Collinson and Z. Kvaček for useful advice and help. The study was supported by Russian Foundation for Basic Research, project N 08-05-00548, SS-4185.2008.5 and Programme N15 Presidium of the Russian Academy of Sciences.

\section{References}

ABLAEV, A.G. 1985. Floras of the Koryakia-Kamchatka region and problems of stratigraphy. 60 Continental Cenozoic deposits. Far East Branch of the Russian Academy of Sciences USSR, Vladivostok. [in Russian]

AKHMETIEV, M.A. 1969. Paleogene and Miocene Flora of the South Far East of the USSR. Moscow. 214 pp. Unpublished MS, Transaction 2 Geological-Hydrogeological Department. [in Russian]

AKHMETIEV, M.A. 1985. The Zaissan basin. Floras at the Eocene-Oligocene boundary (with description of species nova from Buranskaya strata). Transactions of the Academy of Science USSR, Geology Series 11, 76-85. [in Russian]

AKHMETIEV, M.A. 1993. Phytostratigraphy of the Paleogene and Miocene continental deposits of Boreal Asia. Geological Institute of the Academy of Sciences USSR, Transactions 495, 1-143. [in Russian]

AKHMETIEV, M.A. 2007. Paleocene and Eocene Floras of Russia and adjacent regions: climatic conditions of their development. Paleontological Journal 41(11), 1032-1039. [in Russian] DOI 10.1134/S0031030107110020

AKhmetiEV, M.A., AleKsandrova, G.N., BeniAmovskit, V.N., VITUKHIN, D.I., GLEZER, Z., GNIBEDENKO, Z.N., DERGACHEV, V.D., DOLYA, Z.A., ZAPOROZHETS, N.I., KOZLOVA, G.E., KULKOVA, I.A., NIKOLAEVA, I.A., OVECHKINA, M.N., RADIONAVA, E.P. \& STRELNIKOVA, N.I. 2004a. New Data on the marine Paleogene of the Southernwestern Siberian Plate. Paper 1. Stratigraphy and Geological Correlation 12(1), 67-93. [in Russian and English]

AkHmetiev, M.A., AleKsandrova, G.N., BeniAmovskiI, V.N., Vitukhin, D.I., GLEZER, Z., GNiBEDENKO, Z.N., DergacheV, V.D., DOlYa, Z.A., ZAPOROZHETS, N.I., Kozlova, G.E., KulKova, I.A., NikolaEva, I.A., OVECHKINA, M.N., RADIONAVA, E.P. \& STRELNIKOVA, N.I. 2004b. New Data on the marine Paleogene of the Southernwestern Siberian Plate. Paper 2. Stratigraphy and Geological Correlation 12(5), 65-86. [in Russian and English]

AKHMETIEV, M.A. \& BeniamovsKi, V.N. 2006. The Paleocene and Eocene in the Russian Part of West Eurasia. Stratigraphy and Geological Correlation 14(1), 49-72. [in Russian and English] DOI 10.1134/S0869593806010047

AKhMetieV, M.A. \& BRAtseVA, G.M. 1989. Paleogene Flora of Penzhina Bay, 13-31. Geological Institute of the Academy of Sciences USSR (Preprint). [in Russian] 
AKhMetieV, M.A., KezinA, T.V., Kodrul, T.M. \& MANCHESTER, S. 2002. Stratigraphy and flora of the CretaceousPaleogene boundary layers in the southeast part of the ZeyaBureya sedimentary basin, 275-316. In Special volume, dedicated to the memory of the Corresponding member of the USSR Academy of Sciences, Professor Vsevolod Andreevich Vakhrameev (to the $90^{\text {th }}$ anniversary of his birth). GEOS, Moscow. [in Russian]

BACKMAn, J., Moran, K., McInRoy, D.B. \& MAYER, L.A. 2006. Proceedings of the Integrated Ocean Drilling Program, V. 302. 169 pp. US College Station, Texas.

BAIKOVSKAYA, T.N. 1950. Paleocene Flora of Zeya-Bureya plain, 348-381. In Problems of Paleontology 1, Academy of Sciences of USSR, Leningrad. [in Russian]

Baikovskaya, T.N. 1984. Paleocene Flora of Romankulsai (Southern Urals). 79 pp. Nauka, Leningrad. [in Russian]

BARANOV, V.I. 1959. Stages of Flora and Vegetation development during Tertiary period on USSR territory. 364 pp. MS, High School. [in Russian]

BorSuK, M.O. 1956. Paleogene Flora of Sakhalin. All-Union Geological Institute Transactions, new series, 12, 1-132. [in Russian]

BudAnTSEV, L.Y. 1983. History of the Arctic Flora of the Early Cenophytic Epoch. 156 pp. Nauka, Leningrad. [in Russian]

BUDANTSEV, L.Y. 1986. The Early stages of the formation and distribution of the temperate Flora of the Boreal Realm, 60. Komarov Readings 36. Leningrad, Nauka. [in Russian]

BudANTSEV, L.Y. 1997. Late Eocene flora of the Western Kamchatka. 115 pp. Nauka, St. Petersburg. [in Russian]

BudAnTSEV, L.Y. 2006. The Western Kamchatka Early Paleogene Flora. Transactions of the Botanical Institute of the Russian Academy of Sciences 22, 1-160. [in Russian]

BUSHINSKY, G.I. 1958. On the condition bauxite formation and regularity of distribution / Regularity of distribution deposits. Transactions of the Academy of Science, USSR, Geology Series 11, 428-461. [in Russian]

Conwents, H. 1886. Die Flora des Berstein. 2. Die Angiospermen des Bernsteins. 140 pp. Engelmann, Danzig.

CONWENTS, H. 1890. Monographie der baltischen Bernsteinbäume. 151 pp. Engelmann, Danzig.

FEDOTOV, V.V. 1983. Eocene Flora Raichikha of the Amur region. 237 pp. Dep. v VINITI 5.05.83. No. 2274. Ph.D. thesis. [in Russian]

ILJINSKAYA, I.A. 1963. Fossil Flora of the Kiin-Kerish hill, Zaissan basin. Part 2. Botanical Institute of the Academy of Sciences USSR Acta, Series 8, Paleobotany 4, 141-188. [in Russian]

ILJINSKAYA, I.A. 1986. The change of the Flora of the Zaissan basin since the Cretaceous till Miocene, 84-112. In Problems Palaeofloristic and Stratigraphy. [in Russian]

KamaeVA, A.M. 1990. Stratigraphy and Flora of the Cretaceous/Paleogene Transition of the Zeya-Bureya basin. 66 pp. Far East Branch of the Russian Academy of Sciences USSR, Khabarovsk. [in Russian]
KoDRUL, T.M. 1999. Phytostratigraphy of the Paleogene of Southern Sakhalin. Transaction of the Geological Institute of the Russian Academy of Sciences 519, 1-150. [in Russian]

Korovin, E.P. 1932. New Tertiary type of fam. Proteaceae from the Middle Asia. Botanical Magazin 17(5-6), 506-509. [in Russian]

Korovin, E.P. 1934. Vegetation of the Middle Asia and South Kazakhstan. 64 pp. Tashkent \& Moscow.

KRASNOV, A.N. 1910. Introduction to Tertiary flora of South Russia. 253 pp. Publishing house Petshatnik, Kharkov.

KRYSHTOFOVICH, A.N. 1927. The Eocene palm Nypadites burtinii Brongn. from Voznesensk town (Odessa district). Transactions of the Geological Committee 45, 639-642. [in Russian]

Kryshtofovich, A.N. 1936. Materials to the Lower Due Tertiary flora of Sakhalin. Proceedings of the Academy of Sciences of USSR, Geology Series 1936(5), 697-727. [in Russian]

KRYSHTOFOVICH, A.N. 1952. The Raichikha flora, a new link of the Far East Tertiary flora. Botanical Magazin 37(5), 318-331. [in Russian]

KRYShTOFOVICH, A.N. 1958. Fossil floras of the Penzhina bay, Tastakh Lake and Rarytkin Ridge. Botanical Institute of the Academy of Sciences USSR Acta, Series 8, Paleobotany 3, 73-123. [in Russian]

KuLKOVA, I.A. 1973. Palynological study of the Eocene deposits of the Yana-Indigirka lowland. Transaction of the Institute of Geology and Geophysics of the Sibiric Branch of the Academy of Sciences of the USSR 174, 1-113. [in Russian]

MAI, D. 1995. Tertiäre Vegetationgeschichte Europas. 681 pp. Gustav Fischer, Jena.

MAKULBEKOV, N.M. 1972. Eocene flora of Northern Kazakhstan. 177 pp. Nauka, Alma-Ata. [in Russian]

MAKULBEKOV, N.M. 1977. Paleogene flora of Western Kazakhstan and the Lower Volga. 144 pp. Nauka, Alma-Ata. [in Russian]

OZEROV, I.A., ZHINKINA, N.A., EFIMOV, A.N., MACHS, E.M. \& Rodionov, A.V. 2006. Feulgen positive Staining of the cell-nuclei in fossilized leaf and fruit tissues of the Lower Eocene Myrtaceae. Botanical Journal of the Linnean Society 150, 315-321. DOI 10.1111/j.1095-8339.2006.00471.x

PIMENOVA, N.V. 1937. Flora of the Tertiary sandstones on the Dnieper River right side, the Ukraine. Transaction of the Institute of Geology of the Academy of Sciences of the Ukrainian SSR 2, 1-135. [in Russian]

Romanova, E.V. 1970. To the character of the Paleocene flora from the Kiin-Kerish hill (Eastern Kazakhstan). Paläontologische Abhandlungen, Abteilung B - Paläobotanik 3(3/4), 657-668. [in German and Russian]

SCHMALHAUSEN, I.F. 1883-1884. Beiträge zur Tertiärflora Südwest Ruslands. Paläontologische Abhandlungen Berlin 1(4), 285-336.

STANISLAVSKY, F.A. 1950. Paleogene Flora of the Voljantshina village. 19 pp. Doctoral thesis. Abstract. Institute of Geology of the Academy of Sciences of the Ukrainian SSR, Kiev. 
SYCHEVA, O.A. 1977. The Early Paleogene Flora of the Uglgorsk district and its stratigraphical significance, 3-38. In Cenozoic Fauna and Flora of North-Eastern Pacific realm (South Sakhalin). Far East Branch of the Academy of Sciences of the USSR, Vladivostok [in Russian]

TANAI, T. 1967. Climate implication of Tertiary floras in Japan, 89-94. In Tertiary correlations and climatic changes in the Pacific. Tokyo.

TANAI, T. 1970. The Oligocene floras from the Kushiro coal field, Hokkaido, Japan. Journal of the Faculty of Science, Hokkaido University, Series 4, 14(4), 383-514.

VASSILEVSKAYA, N.D. 1957. Badkhys Eocene flora (Turkmenia), 103-176. In Afrikan Nikolaevich Kryshtofovich, Memory issue. Academy of Sciences of the USSR, Moskva, Leningrad. [in Russian]

ZAPOROZHETS, N.I., SinELNIKOVA, V.N. \& AKHMETIEV, M.A. 2006. Organic-walled Phytoplankton from the Paleogene sec- tion of Kamchatka. Stratigraphy and Geological Correlation 14(6), 94-116. [in Russian and English]

DOI $10.1134 / \mathrm{S} 0869593806060062$

ZHILIN, S.G. 1986. The change of ecological types flora of the Ukrainian and south of Middlerussian upland to the Paleogene-Neogene Transition, 72-84. In Problems of Palaeobotany. Nauka, Leningrad. [in Russian]

ZHILIN, S.G. 1989. History of the development of the temperate forest flora in Kazakhstan, USSR from Oligocene to Early Miocene. Botanical Review 55, 205-330. DOI $10.1007 / \mathrm{BF} 02858522$

ZHILIN, S.G. 2005. On the diversity of the flora emerged by the end of the Late Eocene in Kazakhstan, 90-96. In Modern problems of palaeofloristics, palaeophytogeography and phytostratigraphy. Transaction of the International Palaeobotanical Conference, 17-18 May, 2005. Vol. 1. GEOS, Moscow. [in Russian] 